NBER WORKING PAPER SERIES

\title{
DOES FUNCTION FOLLOW ORGANIZATIONAL FORM? EVIDENCE FROM THE LENDING PRACTICES OF LARGE AND SMALL BANKS
}

\author{
Allen N. Berger \\ Nathan H. Miller \\ Mitchell A. Petersen \\ Raghuram G. Rajan \\ Jeremy C. Stein \\ Working Paper 8752 \\ http://www.nber.org/papers/w8752 \\ NATIONAL BUREAU OF ECONOMIC RESEARCH \\ 1050 Massachusetts Avenue \\ Cambridge, MA 02138 \\ February 2002
}

Research support from the following sources is gratefully acknowledged: the National Science Foundation (Rajan, Stein), and the George J. Stigler Center for Study of the State and Economy (Rajan). Thanks also to seminar participants at Yale University and the Federal Reserve Bank of New York, and to Abhijit Banerjee, Michael Kremer and Christopher Udry for helpful comments and suggestions. The views expressed herein are those of the authors and not necessarily those of the National Bureau of Economic Research or the Federal Reserve Board.

(C) 2002 by Allen N. Berger, Nathan H. Miller, Mitchell A. Petersen, Raghuram G. Rajan and Jeremy C. Stein. All rights reserved. Short sections of text, not to exceed two paragraphs, may be quoted without explicit permission provided that full credit, including (C) notice, is given to the source. 
Does Function Follow Organizational Form?

Evidence From the Lending Practices of Large and Small Banks

Allen N. Berger, Nathan H. Miller, Mitchell A. Petersen, Raghuram G. Rajan and Jeremy C. Stein

NBER Working Paper No. 8752

February 2002

JEL No. D21, D23, G21

\begin{abstract}
Theories based on incomplete contracting suggest that small organizations may do better than large organizations in activities that require the processing of soft information. We explore this idea in the context of bank lending to small firms, an activity that is typically thought of as relying heavily on soft information. We find that large banks are less willing than small banks to lend to informationally "difficult" credits, such as firms that do not keep formal financial records. Moreover, controlling for the endogeneity of bank-firm matching, large banks lend at a greater distance, interact more impersonally with their borrowers, have shorter and less exclusive relationships, and do not alleviate credit constraints as effectively. All of this is consistent with small banks being better able to collect and act on soft information than large banks.
\end{abstract}

Allen N. Berger
Board of Governors of the
Federal Reserve System
Division of Research and Statistics
Mail Stop 153
20th and Constitution Avenue, NW
Washington, DC 20551

Raghuram G. Rajan University of Chicago

1101 East 58th Street

Chicago, IL 60637

and NBER

\author{
Nathan H. Miller \\ Board of Governors of the \\ Federal Reserve System \\ 20th and C Streets, NW \\ Washington, DC 20551
}

Mitchell A. Petersen Northwestern University Kellogg Graduate School of Management 2001 Sheridan Road Evanston, IL 60208

\author{
Jeremy C. Stein \\ Harvard University \\ Department of Economics \\ Littauer 209 \\ Cambridge, MA 02138 \\ and NBER \\ jeremy_stein@harvard.edu \\ 617-496-6455
}




\section{$\underline{\text { I. Introduction }}$}

One of the most enduring questions in economics was posed by Coase (1937): What determines the boundaries of the firm? The question is perhaps most often framed in terms of vertical integration-i.e., when can it make sense for upstream and downstream activities to be combined under the roof of a single firm? But one can also ask about the circumstances under which horizontal integration creates value. A good present-day illustration of this version of the question comes from the commercial banking industry, where ongoing consolidation raises the issue of whether the resulting large banks will behave differently than the small banks that they are displacing.

A partial answer to Coase's question comes from the work on transaction-cost economics of Williamson $(1975,1979,1985)$ and Klein, Crawford and Alchian (1978). These authors focus on the hold-up problems that can accompany market transactions, and argue that such problems can be mitigated by having the firm, rather than the market, mediate trade. While this approach is helpful in identifying the advantages of integration (i.e., a reduction in market hold-up problems), it is less clear on the disadvantages. As such, it is somewhat of a one-sided theory_unless one invokes factors outside the model, like unspecified "costs of bureaucracy," it has the awkward implication that efficiency would be best served by placing all of the economy's assets inside a single firm.

The disadvantages of integration emerge much more clearly in the property-rights approach of Grossman and Hart (1986), Hart and Moore (1990), and Hart (1995), henceforth GHM. At its most general level, the central insight of the GHM paradigm is that, in a world of incomplete contracts, agents' ex ante incentives are shaped by the extent to which they have control or authority over physical assets. Thus, for example, if 
firm $\mathrm{A}$ acquires firm $\mathrm{B}$, the manager who was previously $\mathrm{CEO}$ of firm $\mathrm{B}$ may become discouraged now that he is subordinate to the CEO of firm A, and no longer has full control rights over B's assets. As a result, this manager's ex ante (non-contractible) investment may be reduced; herein lies the potential cost of integration.

The GHM property-rights paradigm is an extremely powerful conceptual tool, and it has had enormous influence on the subsequent development of the theory of the firm. But it has proved challenging to construct sharp, decisive empirical tests of the theory. As discussed in Whinston (2001), this is in part due to the fact that the predictions of property-rights models can be very sensitive to specific assumptions, such as the nature of the non-contractible investments that need to be made ex ante. A further difficulty is that because the GHM paradigm focuses on ownership over physical assets as the exclusive source of power and incentives in the firm, it abstracts from other considerations that might be present in a richer, more empirically realistic model.

One strategy for dealing with these problems is to not take the original GHM models too literally as a basis for empirical testing, and to work instead with "secondgeneration" models that build on the basic GHM insights, but that are more tailored to delivering clear-cut comparative static predictions, either for a specific type of investment, or in a particular institutional setting. This strategy is followed by Baker and Hubbard (2000a, 2000b, 2001), whose work centers on the trucking industry, and the question of whether drivers should own the trucks they operate, as well as by Simester and Wernerfelt (2000), who look at the ownership of tools in the carpentry industry.

\footnotetext{
${ }^{1}$ Such considerations include: differentially informed agents as in Aghion and Tirole (1997); incentive structures as in Holmstrom and Milgrom (1994) and Holmstrom (1999); or access to critical resources as in Rajan and Zingales (1998, 2001).
} 
In this paper, we take a broadly similar approach. In contrast to the abovementioned authors, however, our focus is not on how differences in technology influence the ownership of assets. Instead, it is on how the nature of an organization affects both the way that it does business, and the kinds of activities that it can efficiently undertake. In particular, we attempt to understand whether small organizations are better at carrying out certain specific tasks than large organizations.

Our starting point is the model in Stein (2002). This model adopts the basic GHM insight that the allocation of control affects incentives, but does so in a setting that is more specific, and thus yields sharper empirical predictions. The predictions have to do with the differing incentives that are created in large and small firms for the production and use of various kinds of information. The model implies that small firms are at a comparative advantage in evaluating investment projects when the information about these projects is naturally "soft," and cannot be credibly communicated from one agent in the firm to another. In contrast, large firms do relatively well when information about investment projects can be easily "hardened" and passed along within the hierarchy.

A natural industry to apply this model to is banking, where information is critical to the activity of lending. The model suggests that large banks will tend to shy away from small-business lending, because this is an activity that relies especially heavily on the production of soft information, something that is not their strong suit. For example, consider a loan officer trying to decide whether or not to extend credit to a small start-up

\footnotetext{
${ }^{2}$ In this regard, our work is similar in spirit to Mullainathan and Scharfstein (2001). They document how producers of a particular chemical that are integrated with the downstream users of the chemical have investment behavior that differs - in terms of responsiveness to industry price and capacity conditionsfrom those producers that are stand-alones. The common idea is that one can learn something useful by examining in detail how different types of organizations behave when faced with similar tasks. This is a quite different approach than the standard one of trying to explain organizational form (e.g., integration vs. non-integration) based on a variety of industry characteristics.
} 
company that does not have audited accounting statements. The best the loan officer may be able to do is to spend time with the company president in an effort to determine whether she is honest, prudent and hardworking-i.e., the classic candidate for a "character loan." However, given that this information is soft and cannot be verifiably documented in a report that the loan officer can pass on to his superiors, the model predicts (as is explained in more detail below) that his incentives to produce high-quality information are weak when he works inside a large bank.

By contrast, when dealing with a larger company that has a well-documented track record, the decision of whether or not to extend credit can be based more heavily on verifiable information, such as the company's income statements, balance sheet, and credit rating. In this case, the model suggests that a large bank will have no problemindeed, it may do better-at providing incentives for information production.

To test this theory, we make use of a unique data set on small business lending. The data set contains information not only about the small firms in the sample, but also about their primary bank lenders and the nature of the relationship between the two. It thus allows us to investigate a number of hypotheses about how the "technology" of lending depends on variables such as bank size. If, as the theory suggests, large banks are at a comparative disadvantage in the production and use of soft information, one would expect this to influence their methods of lending.

We develop six basic pieces of evidence to support this case. First, and most simply, we find that bigger banks are more apt to lend to firms that are larger or that have better accounting records (a good example of hard information). Second, controlling for firm and market characteristics, we find that the physical distance between a firm and the 
branch office that it deals with is increasing with the size of the bank. This is consistent with the notion that large banks rely less on the sort of soft information that is typically available through personal contact and observation. Third and relatedly, we find that firms do business with large banks in more impersonal ways-i.e., they meet less often face-to-face with their banker, and instead communicate more by mail or phone.

Of course a firm chooses the bank from which it borrows. That is, the match between a firm and its bank is to some extent endogenous, and is likely to be related to firm characteristics. Indeed, our first finding — that bigger banks match up with firms with better accounting records - is evidence of just this endogeneity. This suggests that we need to proceed carefully if, as in our second and third findings, we want to use bank size as a right-hand-side variable to explain certain aspects of the lending relationship. For example, perhaps large banks deal with their customers more impersonally not because they are any less well-suited to personal interaction per se, but because they tend to match with a different type of customer for whom such interaction is less appropriate.

In effort to deal with this potential endogeneity problem, we try instrumenting for bank size with two variables: i) the median size of all banks (weighted by number of branches) in the market where the firm borrows; and ii) a regulatory variable which measures how permissive the firm's state has been with respect to branching. Intuitively, if a firm borrows from a large bank because it is located in a market where there are only large banks (say because regulation has not artificially constrained bank size), this does not reflect an endogenous choice on the part of the firm, but rather an exogenous, geographically-imposed limitation. We find that when we take this instrumental-variables 
(IV) approach, the estimated effect of bank size on distance and on the extent of impersonal communication is even larger than when we do not correct for endogeneity.

Our fourth and fifth findings are that bank-firm relationships tend to be strongerboth more long-lived and more exclusive- when the firm in question borrows from a small bank. These findings also emerge both with and without using IV, but again are more pronounced when an IV approach is employed. They are exactly what one would expect based on the theory, given that the soft information produced by small banks is more likely than hard information to be specific to a given banker and borrower, and hence non-transferable. In other words, the theory suggests that small-bank lending should fit more closely with the kind of model in Rajan (1992), where accumulated soft information binds a borrower to its bank over time.

The sixth and final part of our empirical work is to test whether bank size affects the availability of credit to small businesses. If small firms need lenders that are willing to go deeper and acquire soft information, then we would expect those that are forced to go to large banks to be particularly credit constrained. One measure of the degree to which a firm is rationed by financial institutions is the amount of expensive trade credit it relies on (Petersen and Rajan (1994), Fisman and Love (2000)). We find that all else equal, a firm that borrows from a larger bank is more prone to repay its trade credit late.

Interestingly, this last result holds only when we instrument for bank size. When firms are forced to borrow from large banks because there are no small banks around, they seem to face credit constraints - this is what the IV version of the regression tells us. At the same time, an ordinary regression of credit constraints on bank size reveals an 
offsetting effect due to the endogeneity bias: those firms that are by nature the most difficult credits tend to match with smaller banks, as the theory would suggest.

Our findings relate to a sizeable empirical literature on the banking industry, which we discuss in more detail below. For now, the only point to be made is that while there are many papers that document the reluctance of large banks to make smallbusiness loans, there are only a handful that try, as we do, to examine lending practices directly and to understand how and why large banks' practices differ in such a way as to make them less effective at small-business lending. shedding light on the specific underlying mechanism, we can draw inferences that generalize beyond the banking industry. It is easy to think of a number of other settings where our principal conclusion - that there can be an organizational diseconomy of scale in activities requiring a lot of soft information - would appear to be of some relevance.

The rest of the paper proceeds as follows. Section II briefly reviews the theory that we seek to test, and fleshes out our main hypotheses more fully. Section III introduces our data set. Section IV describes our empirical results. Section V discusses how our results fit with some of the related banking literature, and Section VI concludes.

\section{Hypothesis Development}

\section{A. Overview of the Theory}

The logic of Stein's (2002) model can be sketched with a simple example. Imagine a loan officer in Little Rock who is responsible for deciding which small-

\footnotetext{
${ }^{3}$ On the reluctance of large banks to lend to small businesses, see, e.g., Nakamura (1994), Berger, Kashyap and Scalise (1995), Keeton (1995), Berger and Udell (1996), Peek and Rosengren (1996, 1998), Berger et al (1998), Brickley, Linck and Smith (2000), and Sapienza (2002). Berger, Demsetz and Strahan (1999) provide a survey and more complete references.
} 
business loans are worth making. The quality of the loan officer's judgement will depend on how good a job he has done in producing soft information, which in turn will be a function of his incentives. In the limiting case of a very small bank, the loan officer is also the president of the bank, and as such has the authority to allocate the bank's funds as he sees fit. Given that he can count on having some capital to work with, he knows that his research efforts will not be wasted, and hence his incentives to do research are relatively strong. In other words, the decentralization inherent in having a small bank rewards an agent who develops expertise by ensuring that he will have some capital which he can use to lever that expertise.

In contrast, if the Little Rock loan officer is part of a large multi-branch hierarchy, the following problem arises. Suppose that he spends a lot of effort learning about prospects in his area. But then somebody higher up in the organization decides that overall lending opportunities are better in Tulsa, and sharply cuts the capital allocation for Little Rock. In this case, because he doesn't get a chance to act on the soft information that he has produced, and because he is unable to credibly pass it on, the Little Rock loan officer's research effort goes to waste ${ }^{3}$ Ex ante, this implies that the loan officer does less research in a hierarchical setting. Here the authority to allocate capital is separated from expertise-i.e., the Little Rock loan officer may be left with no capital to work with-which dilutes the incentives to become an expert. This can be

\footnotetext{
${ }^{4}$ More generally, the problem may not be simply one of credibly transmitting raw information to the decisionmaker. To avoid problems of overload, the agent at the top of a large organization may need to see the information in a form that allows for easy comparability across projects. This requirement might result in information being discarded, even if it is in principle communicable.
} 
thought of as a specific manifestation of the key GHM idea that taking control away from an agent tends to weaken his incentives.

To further bring out the intuition of the model with soft information, consider this question: All else equal, will a large banking organization be better at making smallbusiness loans if it set up as single legal entity, or as a multi-bank holding company, with a number of legally distinct subsidiaries? Several authors (e.g., Keeton (1995), and DeYoung, Goldberg and White (1997)) hypothesize that the multi-bank holding company structure is particularly inimical to small-business lending, because it adds extra layers of bureaucracy. However, Stein (2002) argues that just the opposite may be the case. To the extent that this structure makes it harder to move capital across the different subsidiaries, it can act as a partial precommitment by the CEO to run a decentralized operation-i.e., to not reduce individual agents' capital allocations. This should improve their incentives to gather soft information, and thereby benefit small-business lending.

The model works very differently when the information produced by agents can be hardened and passed on to their superiors, as might be the case with the output from a credit-scoring model. Now, large banks may actually generate more investigative effort than small banks. This is because with hard information, agents can become advocates for their units-if a Little Rock loan officer working inside a large bank produces verifiable evidence showing that lending opportunities in his area are strong, he can increase the amount of capital that he is allocated. Here, separating authority from

\footnotetext{
${ }^{5}$ Aghion and Tirole (1997) also argue that agents' incentives may be blunted when they are in a hierarchy. A critical distinction is that in Stein (2002), a hierarchical structure need not weaken incentives-indeed, it only does so when information is soft. In contrast, in Aghion and Tirole, agents are always discouraged when they do not have authority. Thus the models have quite different empirical implications: the AghionTirole model does not say anything about why large banks might be at more of a disadvantage with smallbusiness loans than with credit cards or mortgages.
} 
expertise actually improves research incentives, as lower-level managers struggle to produce enough information to convince their superiors that they should get a larger share of the bank's overall capital budget. ${ }^{0}$

Although the explicit distinction between soft and hard information that Stein (2002) emphasizes is not typically drawn in the applied banking literature, it does correspond closely to the oft-discussed dichotomy between "relationship" lending and "transactions-based" lending. of work that large banks will be at an organizational disadvantage when it comes to relationship lending, but will do better with respect to transactions-based lending. For example, Berger, Demsetz and Strahan (1999) argue that "because of Williamson (1967, 1988) type organizational diseconomies...large complex financial institutions....would reduce services...to those customers who rely on relationships.” (pp. 165-166)

\section{B. Testable Implications}

\section{B.1. The choice of bank}

The most basic implication of the theory is that small banks have a comparative advantage in making loans based on soft information, while large banks have a

\footnotetext{
${ }^{6}$ See also Rajan and Zingales (1998), where withholding ownership spurs effort by encouraging competition for power.

${ }^{7}$ Berger and Udell (2002) define relationship lending as a situation where the bank bases its decisions primarily on information gathered through continuous contact over time with the firm, its owner and other members of the local community. They also identify three types of transactions-based lending, each one having to do with a specific type of objective, readily-observable data: i) financial-statement lending; ii) asset-based lending; and iii) lending based on credit-scoring models.
} 
comparative advantage in making loans based on hard information. ${ }^{8}$ This suggests that, ceteris paribus, firms about which there is more hard information should tend to borrow from larger banks. One potential proxy for whether there is hard information about a firm is its size-large firms are likely to generate hard information themselves to facilitate control over their operations. So we might expect large firms to borrow from large banks. Of course, there may be other reasons why large firms and large banks go together. However, our data set also tells us whether a given firm keeps formal accounting records. This could serve as a proxy for hard information, and we would therefore predict firms with records to be more likely to borrow from larger banks.

\section{B.2. The endogeneity of bank size and our instrumenting strategy}

All the hypotheses that follow relate bank size to various aspects of the bank-firm lending relationship. In other words, we want to use bank size as a right-hand-side variable to explain the nature of the lending technology. But since firms can to some degree choose their banks - as we have just emphasized-there is an obvious endogeneity problem to worry about. In particular, some firm characteristic that we have not controlled for may explain both why the firm chooses a bank of a certain size, as well as the aspect of the relationship we are interested in. For example, an entrepreneur with an MBA degree may be better able to get a hearing from similarly-trained loan officer in a large bank. This entrepreneur may also find it easier to generate periodic spreadsheet reports for the bank that obviate the need for a personal visit. Thus he may be more apt to

\footnotetext{
${ }^{8}$ Other factors outside the model are likely to increase large banks' comparative advantage on the hardinformation dimension. For example, they may also enjoy scale economies in information technology, and in access to the historical data on loan defaults needed to build a good credit-scoring model.
} 
borrow at a distance, and to communicate with the bank impersonally. In this case, we would see large banks lending impersonally and at a distance, but this would not necessarily reflect a causal consequence of bank size.

To address this potential bias, we need one or more instruments which are correlated with a firm's propensity for being matched with a bank of a particular size, but which are uncorrelated with characteristics of the firm that might influence the nature of the lending relationship. In our baseline specifications, we use two instruments: i) the log of the median size of all the banks in the Metropolitan Statistical Area or rural county in which the firm is located (weighted by the number of branches); and ii) the fraction of the previous ten years during which the firm's state was neither a unit banking or limited branching state. The idea is that if a firm is located in a state where regulation has not constrained bank size, and hence where large banks dominate its market, the firm will be forced - independent of its own characteristics - to go to a large bank. We can then examine how this forced match shapes the bank-firm relationship.

Although our median-bank-size instrument varies at the level of the city or rural county, and our regulatory instrument varies only at the state level, the two are closely linked, with a univariate correlation of 0.472 . Not surprisingly, states that have been permissive with respect to branching tend to have larger banks across all of their individual markets. In spite of this commonality, however, one might argue that the state-level regulatory variable is a purer instrument. Perhaps within a given state, some markets have certain attributes that tend to attract both banks of a certain size and firms 
with particular characteristics. For example, a vibrant big-city economy might draw both large banks and MBA-trained entrepreneurs..

An alternative estimation strategy that helps to address this critique is to dispense with the median-bank-size variable, and to use the regulatory variable as the only instrument for bank size. This approach, which we experiment with below, is more conservative, but also considerably less powerful, because it makes use only of acrossstate variation, and loses the within-state across-market variation. Nevertheless, it leads to point estimates that are remarkably similar to those from our baseline instrumenting technique, although the standard errors are of course somewhat higher.

\section{B.3. The effect of bank size on distance and mode of interaction}

Being close to one's customers is likely to facilitate a loan officer's collection of soft information, but to have little impact on his ability to gather hard information. What we have in mind here is that one important way to for the loan officer to gather soft information is through face-to-face interaction with a potential borrower. Hard information, on the other hand, can by definition be easily summarized in a report, and hence can be faxed or emailed anywhere, so that distance is essentially irrelevant.

Now think of a firm that wants to borrow. If it is forced to choose among large banks (because, say, no small banks are around), we would expect the firm to not limit itself to those that are close, knowing that any large bank is unlikely to invest in acquiring soft information, and that its lending technology is therefore more distant-independent.

\footnotetext{
${ }^{9}$ We thank Abhijit Banerjee for raising this point.

${ }^{10}$ Coval and Moskowitz (2001) demonstrate the importance of physical distance for information-gathering, documenting that money managers do better when investing in the stocks of nearby companies.
} 
We would also expect the mode of communication between the firm and the bank to be more impersonal. By contrast, if only small banks are around and the firm is informationally opaque, we would expect it to pick a nearby bank, given that the latter's information acquisition is sensitive to the "shoe-leather" costs of personal visits. We would also expect the contact between the firm and bank to be more personal in nature.

\section{B.4. The effect of bank size on relationship length and exclusivity}

If our findings about distance and mode of interaction do reflect the fact that small banks are better at using soft information, we should see this manifested in two further ways. First, small banks should sustain longer relationships with their borrowers. The soft information that a small bank has gathered over time should give it a comparative advantage over others in providing its client firm with good lending terms. Moreover, because this soft information is not easily transferable by the firm, the banker may have a certain degree of market power (see Sharpe (1990) and Rajan (1992)), which would further tie the firm to it. If, on the other hand, a firm's relationship with a large bank is based on hard information, which is easily communicated to potential new lenders, the additional benefits of staying with the same lender, or the switching costs of moving to a new one, are likely to be lower. So the length of time that a firm and its bank have dealt with each other should be decreasing in bank size.

A second implication, which follows from similar reasoning, is that the likelihood that a relationship between a firm and its bank is an exclusive one-i.e., that the bank is the firm's only lender-should also be decreasing in bank size. In other words, their 
greater reliance on soft information suggests that smaller banks should form both longer and more exclusive relationships with their customers.

\section{B.5. The effect of bank size on credit availability}

Since we argue that small banks form stronger, more information-intensive bonds with their borrowers, we might also expect them to do a better job of easing these firms' credit constraints. If we can document evidence consistent with this prediction, we will have identified an important "real" effect of bank size that would seem to be particularly difficult to explain away with alternative stories.

To form an operational measure of credit constraints, we follow Petersen and Rajan (1994), and look at the fraction of a firm's trade credit that is paid late. As Petersen and Rajan argue, stretching one's trade credit is a very expensive way to obtain finance, and a firm is likely to do so only when it is rationed by institutional lenders. So the final prediction of our theory is that firms should repay a higher fraction of their trade credit late if they borrow from larger banks. This is perhaps the test where it is most critical to correct for the endogeneity of the firm's choice of bank. If our theory is correct, one would expect particularly difficult credit risks (e.g., opaque risky firms) to choose small banks. Without instrumenting for bank size, the test would therefore be biased against finding that small banks improve credit availability.

\section{Data}

\section{A. Sources}

Our primary data source is the Federal Reserve's 1993 National Survey of Small Business Finance (NSSBF), which covers the financing practices of a stratified random 
sample of firms. ${ }^{1}$ To be in the sample, a firm must be a for-profit with fewer than 500 employees. Consequently, the firms in our sample are really quite small, with a mean book value of assets of $\$ 3.0$ million, and a median of $\$ 680$ thousand.

The survey's focus on small firms is ideal for our purposes, for several reasons. First, many of the firms in our sample (about 43 percent) do not have formal financial records. This makes it plausible that soft information might have a relatively important role to play in evaluating their creditworthiness. Second, these firms secure most of their external finance from debt markets, and a predominant share of this comes from banks. Thus there is at least the possibility that being matched with the "wrong" kind of bank could have a meaningful effect on their overall access to finance. A third advantage of examining such small firms is that the decision of whether to borrow from a large or small bank will probably not be driven by regulatory lending limits in most cases. 1.3

Although the survey includes a complete inventory of all of a firm's current loans and lenders, we focus on its most recent loan, and only if that loan is from a bank. This allows us to focus on a fairly static banking environment, and also helps to ensure that we measure the firm's characteristics, as well of those of its bank, at roughly the time the loan was originated. In particular, each observation in our sample is based on a firm that

\footnotetext{
${ }^{11}$ The survey was actually conducted in 1994 and 1995 based on a sample of firms that were in existence at the end of 1993. Some of the information collected — e.g., on the most recent loan the firm has - actually comes from the calendar year 1994.

12 Between $65 \%$ and $90 \%$ of NSSBF firms' outside finance comes from debt (depending on whether "other equity" is classified as inside or outside equity—see Berger and Udell (1998), Table 1). Banks are the source of $68 \%$ of the outside, non-trade credit debt.

${ }^{13}$ The median loan request in our sample is $\$ 125,000$, and $90 \%$ of the loan requests are for less than $\$ 2 \mathrm{M}$. This compares to average bank assets of $\$ 954 \mathrm{M} ; 90 \%$ of the banks have assets larger than $\$ 162 \mathrm{M}$. Thus the $90^{\text {th }}$ percentile of the loan size distribution is only $1.2 \%$ of the $10^{\text {th }}$ percentile of the bank asset distribution. Since banks typically can lend up to 10 percent of their capital to any one firm, regulatory lending limits are unlikely to be breached.
} 
secured a loan from its bank between 1990 and 1994; 88 percent of these loans were originated in either 1993 or 1994.

Each firm is then matched with the specific bank from which it borrows. For the banks, we use the Consolidated Report of Condition and Income (a.k.a. the Call Reports) to obtain balance-sheet variables such as bank assets. We also use the FDIC Summary of Deposits to determine the locations of individual bank branches. Our baseline sample includes 1,131 firms for which we have data on the most recent lender.

\section{B. Variable Definitions}

In the analysis that follows, we work with the following basic variables. First, we have five variables which can be thought of as proxies for the nature of the relationship between the firm and its bank: 1) Distance is the number of miles between the firm and the bank branch or office from which the most recent loan was granted; 2) Impersonal Relationship is a dummy which equals one if the firm primarily communicates with the bank by phone or mail, and which equals zero if the communication is face-to-face; 3 ) Relationship Length is the number of years that the bank has been providing services to the firm; 4) Single Lender is a dummy which equals one if the bank making the most recent loan is the firm's only lender; and 5) Trade Credit Paid Late is the fraction of its trade credit that the firm reports paying when it is past due. 14

Next, there are six variables which capture bank and banking-market characteristics: 1) Bank Size is the assets of the firm's bank, expressed in billions of

\footnotetext{
${ }^{14}$ The survey asks for the proportion of trade credit that is paid late and codes the variables from 1 (none) to 5 (almost all or all). For ease of interpretation, we recode this variable to be between zero and one, where 1 is recoded to be zero and 5 is recoded to be one.
} 
dollars; 2) Number of Branches in Market is the number of branches that the firm's bank has in the MSA or non-MSA rural county in which the firm is located; 3) Bank Age is the number of years the bank has been in existence; 4) Median Bank Size is the median assets across all banks (weighted by branches) in the firm's market; 5) Open Market is the fraction of the ten years prior to our sample period (i.e., 1983-1992) during which the firm's state was neither a unit banking or limited branching state; and 6) Market Herfindahl is the banking-market Herfindahl index for this market. Bank Size will be the key right-hand-side variable of interest in most of our regressions, and both Median Bank Size and Open Market will be used as instruments for Bank Size.

Finally, there are eight variables that measure firm and contract characteristics: 1) Firm Size is the firm's assets, in millions; 2) Firm Age is the number of years the firm has been in existence; 3) Loan Amount is the size of the most recent loan, in millions; 4) Line of Credit is a dummy which takes on the value one if the most recent loan is a line of credit; 5) Loan Collateralized is a dummy which takes on the value one if the most recent loan is secured; 6) Checking Account is a dummy which takes on the value one if the firm also has a checking account with the bank that made its most recent loan; 7) Firm in MSA is a dummy which takes on the value one if the firm is located in an MSA; and 8) Records is a dummy which takes on the value one if the firm's respondent to the NSSBF survey said "yes" when asked if he or she had documentation such as financial statements or accounting records to help in answering the survey questions.

\section{Summary Statistics by Bank Size Class}

Table 1 presents summary statistics for many of the variables, looking at both the full sample (in Panel A), and at subsamples based on bank size (in Panel B). Although 
the firms in our sample are small (less than 500 employees), we still see a significant

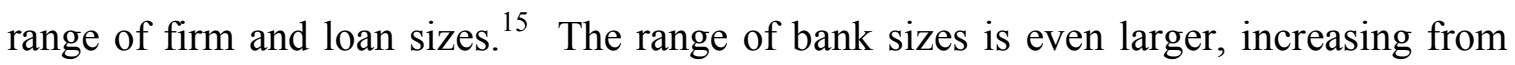
$\$ 163 \mathrm{M}$ in assets at the $25^{\text {th }}$ percentile of the distribution to $\$ 7.69 \mathrm{~B}$ in assets at the $75^{\text {th }}$ percentile. Although these banks are selected because a small firm has borrowed from them, they are not exclusively small banks. In fact, they appear to be somewhat larger than is typical in a comprehensive sample of banks. For example, the $25^{\text {th }}$ percentile of bank assets in our sample $(\$ 163 \mathrm{M})$ corresponds to roughly the $80^{\text {th }}$ percentile of the size distribution of all banks in 1993 (as reported in Kashyap and Stein (2000), Table 1).

As Panel B of Table 1 makes clear, there is a strong univariate correlation between bank size and many of the other variables. For example, mean loan size increases from $\$ 180$ thousand in the smallest class of banks (those with assets below $\$ 100$ million) to $\$ 2.40$ million in the largest size class (those with assets above $\$ 10$ billion). Firm size increases similarly. The fraction of firms with financial records goes from 47.4 percent in the smallest class of banks to 65.4 percent in the largest class.

The aspects of lending relationships that we are interested in also vary across bank size classes in the manner predicted by the theory. The average distance between a firm and its bank rises from 14.9 miles for the smallest class of banks to 71.4 miles for

\footnotetext{
15 The NSSBF does not use an equal-probability sample design but does include a weighting scheme that can be used to make the survey nationally representative. The weights adjust the data based on the firm's MSA status, size class, organization type as well as on the owner's race. We choose not to employ the weights in the analysis presented here. Our hypotheses regarding distance, method of communication, etc., apply with equal force to all observations, and so we weight all observations equally. Our regression results are, however, robust to the weighting procedure. A few notable differences do appear in the variable means. When weighted, average distance drops from 26.053 miles to 11.755 miles, average firm size drops from $\$ 3.003$ million to $\$ 0.951$ million, and average loan amount drops from $\$ 1.001$ million to $\$ 0.285$ million. All of this is consistent with the NSSBF's design, which under-samples the very smallest firms.

${ }^{16}$ The size measures for firms and banks are highly skewed. We take natural logs of all size measures before doing our regressions. This leads to more symmetric distributions. For similar reasons, we also use $\log$ transforms of Distance, Relationship Length, Number of Branches in Market, Bank Age and Firm Age in the regressions. In all cases, the transformed variables have means and medians that are quite similar.
} 
the largest. Relatedly, the incidence of impersonal communication increases from 16.8 percent among the smallest banks to 40.6 percent among the largest banks. Mean relationship length is 9.4 years in the smallest class of banks, and 7.4 years in the largest class. The incidence of exclusive relationships is 61.6 percent among the smallest banks, and 41.0 percent among the largest banks.

\section{Regression Results}

\section{A. The Choice of Bank}

We want to start by understanding what determines the size of the bank from which a firm borrows. In column 1 of Table 2, we use OLS to regress Ln(Bank Size) against the firm and contract characteristics: $\operatorname{Ln}($ Firm Size $) ; \operatorname{Ln}(1+$ Firm Age); Ln(Loan Amount); Line of Credit; Loan Collateralized; Checking Account; Firm in MSA; and Records. The regression also includes dummies — not shown in the table—-for the firm's industry (construction, retail or services) as well as for the year in which the most recent loan was made.

As expected, bank size is strongly correlated with both the size of the firm in question and the size of the loan. If the size of the firm and the size of the loan both double, the regression tells us that bank assets increase by about 40 percent. ${ }^{1}$ But perhaps the most interesting result from this regression is the coefficient on Records, which is 0.240 , and is significant at the five percent level. Controlling for firm size, firms that have financial records borrow from banks that are roughly 24 percent larger. This is

\footnotetext{
${ }^{17}$ Previous work has documented that large banks allocate a lesser fraction of their overall portfolio to the category of "small-business lending." However, we are not aware of any previous evidence that directly demonstrates - as we do - that within this general category, large banks systematically avoid the very smallest of the small firms.
} 
consistent with the idea that all else equal, larger banks are at a comparative advantage in lending to firms for which hard information is more readily available.

As discussed above, in our subsequent regressions we will use $\operatorname{Ln}($ Bank Size) as an explanatory variable, and we will employ Ln(Median Bank Size) and Open Market as instruments for $\operatorname{Ln}($ Bank Size). In column 2 of Table 2, we display the first-stage regression that underlies this instrumenting procedure. In particular, we keep Ln(Bank Size) on the left, and add to the specification of column 1 the following bank and banking-market variables: Ln(Median Bank Size); Open Market; Ln(1 + Number of Branches); Ln(1 + Bank Age); and Market Herfindahl. All of the right-hand-side variables in column 2 of Table 2 will be controls in future regressions, except Ln(Median Bank Size) and Open Market, which will serve as the instruments for Ln(Bank Size). The main point to draw from this regression is that both Ln(Median Bank Size) and Open Market appear sufficiently correlated with Ln(Bank Size) to be viable instruments. They attract economically large coefficients, and are highly statistically significant, with t-stats of 6.9 and 3.0 respectively. 1.8

\section{B. The Distance Between Firms and Their Banks}

Table 3 examines the link between bank size and distance. In column 1, we run an OLS regression in which the dependent variable is $\operatorname{Ln}(1+$ Distance). The explanatory variables include the bank and banking-market characteristics (Ln(Bank Size);

\footnotetext{
${ }^{18}$ We also considered using as instruments two other regulatory variables: i) the fraction of the previous ten years that the firm's state allowed interstate bank-holding-company expansion; and ii) the proportion of the nation's banking assets that, on average over the last ten years, were allowed to compete in the firm's state. However, both of these variables were insignificant when added to the first-stage regression, and contributed essentially no explanatory power.
} 
$\operatorname{Ln}(1+$ Number of Branches $) ; \operatorname{Ln}(1+$ Bank Age $)$; and Market Herfindahl $)$ as well as the firm and contract characteristics ( $\operatorname{Ln}($ Firm Size $) ; \operatorname{Ln}(1+$ Firm Age); Ln(Loan Amount); Line of Credit; Loan Collateralized; Checking Account; Firm in MSA; and Records). In column 2, we run the same basic regression by IV, using Ln(Median Bank Size) and Open Market as instruments for $\operatorname{Ln}($ Bank Size). These regressions, and all those that follow, also continue to include suppressed dummies for the firm's industry and the year the most recent loan was made.

Consistent with our theoretical prediction, firms that are customers of larger banks borrow at substantially greater distances. Both the OLS and the IV coefficients are statistically significant at the one-percent level, and the IV coefficient is larger in magnitude, 0.296 versus 0.184 . According to the IV estimate, increasing bank size from $\$ 163 \mathrm{M}$ in assets (the 25 th percentile) to $\$ 7.69 \mathrm{~B}$ in assets (the 75 th percentile) raises the predicted distance between a firm and its lender by 114 percent.

It is also worth briefly discussing some of the other controls in the regression and their importance. First, and not surprisingly, we find that the number of branches that the firm's lender has in the market is an important determinant of distance. Since larger banks naturally have more branches than small banks, it is especially important that we control for the number of branches in our tests. ${ }^{1.9}$ One way to think about this control is that what the regression is really telling us is that the distance between a firm and its bank is positively related to the size of the bank outside of the firm's local market. In other words, if the bank adds branches outside of the firm's market, distance goes up, but if the

\footnotetext{
${ }^{19}$ In an OLS regression without this control, we still find that Ln(Bank Size) has a statistically significant effect on $\operatorname{Ln}(1+$ Distance), but the coefficient is quite a bit smaller-it drops from 0.184 to 0.048 (t-stat = 2.4). In an IV regression without the control, the coefficient on $\operatorname{Ln}$ (Bank Size) is insignificantly small.
} 
bank adds branches inside the firm's market, distance goes down, for the obvious mechanical reasons. ${ }^{\text {[ }}$

We also find that older firms tend to be closer to their banks. At first, this seems puzzling because older firms might be expected to have better-established reputations (Diamond (1991)), which should facilitate borrowing at a distance. The answer to the puzzle may be that firm age proxies for when the relationship was started. ${ }^{\text {Cyrnak }}$ and Hannan (2000) and Petersen and Rajan (2002) find that the distance between firms and their banks has been growing over time, partly because of the greater availability of hard information. So older firms may be closer to their banks because they started their relationships at a time when little hard public information was available about them. Finally, firms that have checking accounts with their banks are closer to them. This replicates a finding in Petersen and Rajan (2002), and may be explained by the greater necessity of making physical trips to the bank when one has a checking account with it.

A couple of other points deserve mention. The literature on bank consolidation has raised the question of whether banking mergers disrupt borrower-lender relationships, especially those that rely on soft information. Thus when we find that larger banks are more likely to lend at a distance, we want to be sure that our bank size result is not due only to the effect of mergers. To test this, we rerun our basic specification, adding two controls for bank mergers (in regressions not reported in the tables). These variables are individually insignificant and make no material difference to our principal conclusions.

\footnotetext{
${ }^{20}$ We have verified this statement by re-running the basic OLS and IV regressions in Table 3, replacing Ln(Bank Size) with the log of one plus the number of branches that the bank has outside the market in question. In both cases, this variable also attracts a strongly significant positive coefficient.

${ }^{21}$ Indeed, if we add $\operatorname{Ln}(1+$ Relationship Length $)$ to the regression, the coefficient on $\operatorname{Ln}(1+$ Firm Age $)$ falls.
} 
In a similar spirit, we also add two controls for bank health; again our results are unaffected. $^{\text {[2 }}$

A last issue is that any given bank in our sample can be either a stand-alone bank or part of a multi-bank holding company. Our measure of bank size does not include the assets of other banks that are part of the same multi-bank holding company. Moreover, 65 percent of our sample firms borrow from banks that are part of multi-bank holding companies.

As discussed in Section II, the effects of being part of a holding-company structure are theoretically ambiguous. On the one hand, it can be argued that putting a bank inside a larger holding company increases the bureaucracy its loan officers have to deal with, which might make lending based on soft information more difficult. On the other hand, the model of Stein (2002) implies that if decisions within the holding company can be credibly decentralized to the bank level, then the size of the holding company outside of the specific bank in question should not matter much.

To examine this issue, we include two additional explanatory variables in our regressions: i) a dummy for whether the bank is part of a multi-bank holding company; and ii) the log of assets of the other banks in the multi-bank holding company, if any exist. (This variation is not reported in the tables.) Interestingly, we find that, keeping the assets of the firm's own bank constant, neither of these two holding-company variables has an economically or statistically significant effect on the distance between a firm and its bank. Moreover, parallel results apply for all of the other specifications that we

\footnotetext{
${ }^{22}$ As added controls, we include a dummy variable for each of the following: whether a bank was the surviving bank in a merger in the last three years; whether the bank changed top-tier holding companies in the last three years; whether the bank's equity to asset ratio was in the bottom 10 percent of our sample; and whether the bank's ratio of non-performing loans to all loans was in the top 10 percent of our sample.
} 
examine below-i.e., those which seek to explain the mode of communication, the length and exclusivity of relationships, and the extent of credit constraints. In each case, the size of the bank that the firm borrows from matters, but the size of the rest of the bank's holding company generally does not. ${ }^{\text {目 }}$

This pattern suggests that it is not simply the absolute size of an organization that is crucial, but also the degree of credible decentralization that can be achieved. If lending decisions (especially to small firms) are made at the bank level, then it is the size of the bank rather than the size of the rest of the holding company that will be important in shaping the lending technology.

\section{The Mode of Conducting Business: Personal vs. Impersonal}

In Table 4, we investigate the link between bank size and the mode of communication. The right-hand-side variables are exactly the same as in Table 3, and the left-hand-side variable is now Impersonal Relationship. Also, given the dichotomous nature of the Impersonal Relationship variable, we run the regressions by logit, instead of by OLS. ${ }^{24}$ In column 1, we use Ln(Bank Size) directly in the logit regression, and in column 2 we instrument for $\operatorname{Ln}($ Bank Size) by replacing it with its fitted value from the first-stage regression in column 2 of Table 2.

Both the ordinary logit and the IV version yield strong, statistically significant estimates for the influence of bank size on the mode of communication, though as before the IV estimate is noticeably bigger. Based on the IV coefficient, an increase in bank size

\footnotetext{
${ }^{23}$ Even in the few specifications where the size of the rest of the holding company attracts a statistically significant coefficient, this coefficient is an order of magnitude smaller than that for own bank size.

${ }^{24}$ Though our results are virtually identical if we use OLS instead.
} 
from the 25 th to the 75 th percentile raises the probability of impersonal communication from 15 percent to 38 percent. 25

As with distance, the number of branches that the firm's bank has in the local market also affects the way in which the firm and the bank interact. In this case, having more in-market branches leads to significantly less impersonal communication, as would be expected.

Impersonal communication and physical distance are clearly related-it is more difficult to visit a distant bank in person. As a more stringent test, we can ask if there is an effect of bank size on the mode of communication, even after controlling for distance. In an unreported regression, we find that when we add $\operatorname{Ln}(1+$ Distance $)$ to the righthand-side of the IV specification, the coefficient on Ln(Bank Size) drops from 0.324 to 0.160. Although this still represents an economically interesting magnitude, the point estimate is no longer statistically significant.

With respect to the firm characteristics, we find strong evidence that larger firms are more likely to communicate impersonally with their bankers, which is not surprising. At the same time, controlling for size, older firms are less likely to communicate impersonally. This is at least in part driven by the earlier finding that older firms are physically closer to their banks. There may also be a vintage effect at work, whereby managers of older firms started off their careers interacting with their bankers face-toface, and have not changed their ways, even as the technology of banking has evolved.

\footnotetext{
${ }^{25}$ To do this calculation, and the similar ones that follow, we set all the other right-hand-side variables in the regression to their mean values, and simply vary $\operatorname{Ln}($ Bank Size) as indicated.

${ }^{26}$ In the un-instrumented logit specification, adding $\operatorname{Ln}(1+$ Distance $)$ drops the coefficient on $\operatorname{Ln}($ Bank Size) from 0.196 to 0.096 , but in this case the coefficient remains significant at the 10 percent level.
} 
We also find that firms that have checking accounts with the bank are more inclined to meet with their banker face-to-face. ${ }^{27}$

\section{The Effect of Bank Size on Relationship Length and Exclusivity}

Table 5 looks at the effect of bank size on relationship length. The structure is identical to that of Table 3, except that the dependent variable is now $\operatorname{Ln}(1+$ Relationship Length). As can be seen, relationships are significantly shorter when the firm borrows from a larger bank. According to the IV specification in column 2 of Table 5, an increase in bank size from the $25^{\text {th }}$ to the $75^{\text {th }}$ percentile cuts the predicted length of a relationship almost in half, shrinking it from 8.8 to 4.5 years.

It should be noted that the estimated coefficient on $\operatorname{Ln}($ Bank Size) is nearly three times higher in column 2, where we use IV, as compared to column 1, where we use OLS. Indeed, the theory suggests that it ought to be particularly important to deal with the endogeneity of bank size here, since firms may be more prone to switch to small banks - thereby setting the relationship-length clock back to zero-if they get into trouble and become the sort of "difficult" credits for whom soft information is especially important. This would obviously make it hard to find an OLS association between small banks and longstanding relationships. 28

Table 6 analyzes the exclusivity of banking relationships, putting Single Lender on the left-hand side of the regressions. As in Table 4, the regressions are run with logit,

\footnotetext{
${ }^{27}$ Adding $\operatorname{Ln}(1+$ Distance $)$ to the regression makes the coefficients on Ln(1 + Firm Age $)$ and Checking Account decline, suggesting that these terms are indeed serving in part as distance proxies.

${ }^{28}$ Based on a Hausman (1978) test, we can explicitly reject the hypothesis that bank size is exogenous in this regression ( $\mathrm{t}$-statistic $=2.5)$.
} 
given the dichotomous nature of the dependent variable. According to the IV specification, the effect of bank size on exclusivity is extremely strong: an increase in bank size from the $25^{\text {th }}$ to the $75^{\text {th }}$ percentile reduces the probability of an exclusive relationship by almost 50 percentage points, from 74 percent to 27 percent.

Again, we see the importance of instrumenting, as the coefficient on Ln(Bank Size) goes from -0.096 in the ordinary logit to -0.526 in the instrumented version. And again, this makes perfect sense in light of the theory. Petersen and Rajan (1994) show that troubled firms are more likely to have multiple relationships - presumably as they cast around for someone willing to accommodate their needs - and our theory suggests that troubled firms should also be more prone to match with small banks. Hence we would expect the non-instrumented coefficient to be significantly biased towards zero.

At this juncture, it may be useful to ask whether the effects of bank size on distance and on the mode of interaction work only indirectly through the kind of relationship that is formed (long and exclusive with small banks, short and non-exclusive with large banks), or whether there is a direct effect also. One way to test this is to include both $\operatorname{Ln}(1+$ Relationship Length $)$ and Single Lender as additional controls in the regressions of Tables 3 and Table 4, where the dependent variables are $\operatorname{Ln}(1+$ Distance $)$ and Impersonal Relationship, respectively. In both cases, the coefficients on $\operatorname{Ln}($ Bank Size) continue to be strongly statistically significant and only slightly diminished in magnitude, suggesting that bank size indeed has an important independent effect.

\section{E. Bank Size and Credit Availability}

We now turn to our final test. Thus far, we have argued that soft information is likely to be important in evaluating the creditworthiness of small firms, and that small 
banks have a comparative advantage in acquiring and acting on such soft information, which is why they can form stronger relationships with the firms in our sample. But do these stronger relationships translate into more financing? In other words, do they have meaningful real effects?

The problem in measuring the availability of credit is that we cannot simply look at the amount of debt on a firm's balance sheet, for that will reflect both demand and supply considerations. But we can use an alternative approach, due to Petersen and Rajan (1994). The idea is that if banks (or any other intermediary) limit the credit extended to a firm, the firm will be forced to borrow from a more expensive source. Holding investment opportunities constant, the amount borrowed from the more expensive sources should measure the degree of credit rationing by banks.

Petersen and Rajan $(1994,1995)$ point to stretched trade credit as an extremely costly source of marginal finance, and argue that the fractional share of a firm's trade credit that is paid late may provide a reliable measure of the extent to which the firm is rationed. $^{29}$ Older and larger firms, which are presumably less constrained by banks, pay less of their trade credit late. Similarly, firms that have long-term relationships with their banks also pay less of their trade credit late.

In Table 7, we repeat our basic specification, putting Trade Credit Paid Late on the left-hand-side. Given that this variable is bounded between zero and one, we run the regressions with a two-sided Tobit procedure. ${ }^{30}$ It should also be noted that the number

\footnotetext{
${ }^{29}$ For example, firms in the retail business often use the 2-10-net-30 rule (Smith (1987)). According to this rule, there is a discount of 2 percent if the amount due is paid within 10 days; otherwise payment must be made within 30 days. Foregoing the 2 percent discount is therefore equivalent to borrowing at an annual rate of 43.5 percent, which is significantly higher than the highest interest rate that firms in our sample pay.

${ }^{30}$ Again, however, we get essentially identical results—-both with and without instrumenting — if we use ordinary least squares instead of Tobit.
} 
of observations in Table 7 is reduced from 1,131 to 546, because we do not have the trade-credit data for all of the firms in our sample.

It is in these regressions that instrumenting for bank size is most important. Ln(Bank Size) attracts a small and statistically insignificant coefficient in column 1, when we enter it directly in the regression. But when we instrument for it in column 2 with Ln(Median Bank Size), the coefficient becomes statistically significant and economically large. In particular, the IV estimate implies that an increase in bank size from the $25^{\text {th }}$ percentile to the $75^{\text {th }}$ percentile raises the fraction of trade credit that is paid late by 17 percentage points, from 26 percent to 43 percent. The bottom line is that firms that are forced to borrow from large banks appear to be substantially more credit constrained than those that can borrow from small banks.

When we test formally whether bank size is exogenous in this model, we reject the hypothesis, with a p-value of 0.06. This is seen in the Hausman (1978) test in column 3 of Table 7. The sign of the endogeneity bias, however, is again interesting. The endogenous portion of bank size (i.e., the residual from the first-stage regression in column 2 of Table 2) is negatively correlated with Trade Credit Paid Late. Put simply, to the extent that they can choose, firms that are more credit rationed pair up with smaller banks. This endogenous pattern of firm-bank matching fits with both the theory, and with all of the other evidence that we have documented so far. Given that small banks are better at building relationships based on soft personal information, we should expect those firms that are having a hard time raising finance to be especially likely to turn to small banks for help. 


\section{F. Robustness: Instrumenting With Only the State-Level Regulatory Variable}

As noted above, it is possible to raise questions about the validity of one of our instruments, Ln(Median Bank Size): one can hypothesize that some markets have certain attributes that tend to attract both banks of a certain size and firms with particular characteristics. So as an alternative, we try dropping $\operatorname{Ln}($ Median Bank Size) and using the state-level regulatory variable Open Market as our only instrument.

On the one hand, Open Market is sufficiently correlated with Ln(Bank Size) that it would appear to be a workable instrument on its own - the univariate correlation between the two variables is 0.227 .3 On the other hand, it is a weaker instrument than Ln(Median Bank Size), which has a correlation of 0.490 with $\operatorname{Ln}($ Bank Size). Thus this approach, while more conservative, also sacrifices considerable power.

Comfortingly, the results that we get when using Open Market as the only instrument are generally very close to those obtained with the two instruments together. ${ }^{22}$ Moreover, if we are willing to adopt the identifying assumption that Open Market is exogenous, we can for each of our left-hand-side variables conduct a specification test of the hypothesis that $\mathrm{Ln}$ (Median Bank Size) is exogenous as well. This hypothesis is never

\footnotetext{
${ }^{31}$ In a multiple regression analogous to that in column 2 of Table 2, with Ln(Bank Size) on the left, but Ln(Median Bank Size) dropped, Open Market attracts a point estimate of 0.878 and a t-stat of 6.58 .

32 In the Distance regression, we report in Table 3 an IV coefficient of 0.296 on $\operatorname{Ln}($ Bank Size); this coefficient changes to 0.362 when we use Open Market as our only instrument. With Impersonal Relationship, the IV coefficient on $\operatorname{Ln}$ (Bank Size) goes from 0.324 to 0.207 , with Relationship Length it goes from -0.150 to -0.189 , with Single Lender it goes from -0.526 to -0.485 , and with Trade Credit Paid Late it goes from 0.044 to 0.028 . In spite of the increased standard errors, the estimates for Distance, Relationship Length and Single Lender continue to be highly statistically significant (with p-values of $0.002,0.002$ and 0.017 respectively). The estimates for Impersonal Relationship and Trade Credit Paid Late, however, are no longer significant.
} 
rejected, which lends further support to the notion that $\operatorname{Ln}$ (Median Bank Size) is a legitimate instrument.

\section{Connection to the Banking Literature}

Our findings complement those from a substantial existing empirical literature on banks' small-business lending practices. Although we cannot provide a full survey of this earlier work, we can sketch some of its broad contours, in an effort to show how what we have done fits in. A first category of research has employed regulatory data on banks (such as the Call Reports and the Summary of Deposits used in this paper), without being able to match these data to information on the small businesses doing the borrowing. These studies typically find that large banks allocate far lower proportions of their assets to small-business loans than do small banks (e.g., Berger, Kashyap, and Scalise (1995)), and that ratios of small-business loans to assets tend to decline after large banks are involved in mergers and acquisitions (e.g., Peek and Rosengren (1998), Strahan and Weston (1996, 1998), and Berger, Saunders, Scalise, and Udell (1998)).

A second category of work has examined data on small businesses (such as the NSSBF survey that we use) but again, without being able to match these data to information on the banks doing the lending. These studies find that stronger bankborrower relationships are generally associated with better treatment for borrowers, in terms of lower interest rates and reduced collateral requirements (Berger and Udell

\footnotetext{
${ }^{33}$ In each case, we implement the test by taking the residuals from the second-stage equation and regressing them on the exogenous variables and the two instruments. The sample size times the resulting $\mathrm{R}^{2}$ is distributed as a Chi-squared with one degree of freedom (Hausman (1983)). As an example, in the case of the Distance model, the test statistic is 0.68 , with a p-value of 0.41 .

${ }^{34}$ Recent research suggests that these effects of mergers may be offset to a degree by increases in supply from other banks in the local market (e.g., Berger, Saunders, Scalise, and Udell (1998)).
} 
(1995)), increased credit availability (Petersen and Rajan, (1994, 1995), Cole (1998)), and greater protection against interest-rate shocks (Berlin and Mester (1998)). While all of these results help make the case that the soft information embedded in a banking relationship is valuable, none of them can speak to the question of what kind of bank is best able to generate and act on soft information.

Finally, a handful of studies have used regulatory data on banks that are matched to their small-business borrowers, as in this paper. It has been found that large banks more often lend to larger, older, more financially secure firms (Haynes, Ou, and Berney (1999)), and to firms that borrow from multiple banks (Berger, Klapper, and Udell (2001)). Also, banks in markets that are dominated by large banks charge lower interest rates (Berger, Rosen, and Udell (2001)). All of these pieces of evidence fit with the idea that, within the general class of small-business loans, large banks systematically try to pick off the largest, safest and easiest-to-evaluate credits. ${ }^{3 .}$ But it seems fair to say that none of them gets at the underlying mechanism that creates this pattern of behavior.

To our knowledge, only one previous paper has tried to directly examine how lending practices themselves differ between large and small banks. Cole, Goldberg and White (1999) use survey data to look at the loan approval process across banks of different sizes. They find that for large banks (over $\$ 1$ billion in assets), approvals are based primarily on standard criteria obtained from financial statements-a so-called "cookie cutter" approach. In contrast, hard financial numbers have less explanatory

\footnotetext{
${ }^{35}$ Consistent with these findings, a study combining bank data with loan-contract data (but no information on the small businesses) found that large banks charge relatively low interest rates and have low collateral requirements for small-business loans (Berger and Udell (1996)).
} 
power (in an $\mathrm{R}^{2}$ sense) for the approval decisions of small banks. This is consistent with the idea that small banks base their decisions more heavily on soft information, and ties in nicely with our results.

\section{$\underline{\text { V. Conclusions }}$}

While there has been much theoretical work by economists on the Coasian topic of organizations and their boundaries, there has been far less empirical work. Moreover, a particularly under-explored set of empirical issues has to do with the ways in which an organization's form affects its ability to carry out different types of functions. The goal of this paper has been to take some first steps towards addressing these issues.

Our analysis is based on the premise that in small organizations, the center of decision-making authority is likely to be close to the point of information collection. According to Stein (2002), this creates strong incentives for soft-information production in small organizations. In contrast, large organizations have a tougher time incentivizing their employees to produce soft information, but tend to do well with respect to the creation of hard information. Large organizations also benefit from having broader internal capital markets-i.e., conditional on having acquired some hard information, they have more scope for actively reallocating resources based on this information. The bottom line is that one might expect small organizations to have a comparative advantage over large ones in activities that require the processing of a lot of soft information, and for the reverse to be true in activities that rely mostly on hard information.

In an effort to test this theory, we examine how banks of different sizes approach the task of small-business lending. We find that large banks lend primarily to larger 
firms with good accounting records, while small banks lend to more difficult credits. We also find that correcting for the endogeneity of the bank-firm match, large banks lend at a greater distance, interact more impersonally with their borrowers, have shorter and less exclusive relationships, and are not as effective at alleviating credit constraints. These effects are both statistically significant and economically large in magnitude, and they are all consistent with the hypothesis that small banks have a comparative advantage in lending based on soft information.

From a policy perspective, our results suggest that bank consolidation may raise meaningful concerns for small firms. Moreover, the key issue may be not so much about banks having market power in the traditional Herfindahl-index sense; rather, one may want to focus on the degree to which firms have choice over the size of the bank they do business with. For it is when they have no choice and therefore have to borrow from large banks that our sample firms appear most prone to being credit constrained.

A similar policy-related observation can be made about the appeal to developing countries of encouraging entry by large multinational banks. Having such foreign banking giants set up shop in a developing economy no doubt has a number of significant benefits. For example, they are probably more likely to be stable and financially sound. They may also be less likely to engage in the sort of corrupt related-lending practices documented by LaPorta, Lopez-de-Silanes and Zamarripa (2001). Without denying the importance of these factors, our analysis points to a potential tradeoff. If large foreign banks substantially crowd out smaller domestic ones, this could have a harmful effect on the supply of loans to informationally opaque small businesses. 
Finally, our results suggest that the standard practice in many countries of setting up large bureaucratic organizations to provide subsidized credit to small businesses (or alternatively, of forcing large banks to do so), may not be very effective. It may make more sense to target subsidies through smaller financial intermediaries, who can better incorporate soft information into their credit decisions.

While our analysis has focused on the banking industry, there are reasons to believe that the conclusions might generalize to a variety of other settings. Smallbusiness lending is not unique in its reliance on soft information. Other relationshipbased activities such as investment banking, consulting, and law also make heavy use of soft information. So too do certain kinds of research and new product development. ${ }_{6}$ Even some governmental activities, such as law enforcement, may require the creation and efficient use of substantial amounts of soft information. Our results suggest that, in all of these cases, organizational structure may play a crucial role in determining how effectively the job at hand is carried out. It would be nice to study some of these other activities in detail, to see if this hypothesis is borne out more broadly in the data.

We have also found preliminary evidence-from the holding-company-level data-which seems to indicate that credible decentralization of decision-making can offset the effects of raw organizational size. This raises the possibility that a large organization might, at least to a degree, be able to enjoy the best of both worlds if it sets up an internal structure that achieves the right level of decentralization. Again, this is a conjecture that would greatly benefit from further empirical investigation.

\footnotetext{
${ }^{36}$ For example, when a company decides whether or not to allocate resources to a small group of scientists working on a new technology, it may have to do so based not on hard documented data about the potential payoffs to investment, but instead on a veteran supervisor's informed gut feeling.
} 


\section{References}

Aghion, Philippe, and Jean Tirole, 1997, Formal and real authority in organizations, Journal of Political Economy 105, 1-29.

Baker, George P., and Thomas Hubbard, 2000a, Make versus buy in trucking: Asset ownership, job design and information, Working Paper, Harvard Business School.

Baker, George P., and Thomas Hubbard, 2000b, Contractibility and asset ownership: Onboard computers and governance in US trucking, Working Paper \#7634, National Bureau of Economic Research.

Baker, George P., and Thomas Hubbard, 2001, Empirical strategies in contract economics: Information and the boundary of the firm, American Economic Review Papers and Proceedings 91, 189-194.

Berger, Allen N., Rebecca S. Demsetz, and Philip E. Strahan, 1999, The consolidation of the financial services industry: Causes, consequences, and implications for the future, Journal of Banking and Finance 23, 135-194.

Berger, Allen N., Anil K Kashyap, and Joseph M. Scalise, 1995, The transformation of the U.S. banking industry: What a long, strange trip it's been, Brookings Papers on Economic Activity, 55-218.

Berger, Allen N., Leora F. Klapper, and Gregory F. Udell, 2001, The ability of banks to lend to informationally opaque small businesses, Journal of Banking and Finance $25,2127-2167$.

Berger, Allen N., Richard Rosen, and Gregory F. Udell, 2001, The effect of market size structure on competition: The case of small business lending, Working Paper, Federal Reserve Board.

Berger, Allen N., Anthony Saunders, Joseph M. Scalise, and Gregory F. Udell, 1998, The effects of bank mergers and acquisitions on small business lending, Journal of Financial Economics 50, 187-229.

Berger, Allen N., and Gregory F. Udell, 1995, Relationship lending and lines of credit in small firm finance, Journal of Business 68, 351-382.

Berger, Allen N., and Gregory F. Udell, 1996, Universal banking and the future of small business lending, in A. Saunders and I. Walter eds.: Financial System Design: The Case for Universal Banking ( Irwin, Burr Ridge IL).

Berger, Allen N. and Gregory F. Udell, 1998, The economics of small business finance: The roles of private equity and debt markets in the financial growth cycle, Journal of Banking and Finance 22, 613-673. 
Berger, Allen N., and Gregory F. Udell, 2002, Small business credit availability and relationship lending: The importance of bank organizational structure, Economic Journal, forthcoming.

Berlin, Mitchell, and Loretta Mester, 1998, On the profitability and cost of relationship lending, Journal of Banking and Finance 22, 873-97.

Brickley, James A., James S. Linck and Clifford W. Smith, 2000, Boundaries of the firm: Evidence from the banking industry, Working Paper, Rochester University.

Coase, Ronald, H., 1937, The nature of the firm, Economica 4, 386-405.

Cole, Rebel A., 1998, The importance of relationships to the availability of credit, Journal of Banking and Finance 22, 959-77.

Cole, Rebel A., Lawrence G. Goldberg, and Lawrence J. White, 1999, Cookie-cutter vs. character: The microstructure of small business lending by large and small banks, in J.L. Blanton, A. Williams and S.L.W. Rhine eds.: Business Access to Capital and Credit (Federal Reserve System Research Conference), 362-389.

Coval, Joshua and Tobias Moskowitz, 2001, The geography of investment: informed trading and asset prices, Journal of Political Economy 4, 811-841.

Cyrnak, A., and T.H. Hannan, 2000, Non-local lending to small businesses, Working Paper, Federal Reserve Board.

DeYoung, Robert, Lawrence G. Goldberg, and Lawrence J. White, 1997, Youth, adolescence and maturity of banks: Credit availability to small business in an era of banking consolidation, Working Paper, New York University.

Diamond, Douglas W., 1991, Monitoring and reputation: The choice between bank loans and directly placed debt, Journal of Political Economy 99, 689-721.

Fisman, Raymond J. and Inessa Love, 2000, Trade credit, financial intermediary development and industry growth, Working Paper, Columbia University.

Grossman, Sanford J., and Oliver D. Hart, 1986, The costs and benefits of ownership: A theory of vertical and lateral integration, Journal of Political Economy 94, 691719.

Hart, Oliver D., 1995, Firms, Contracts, and Financial Structure (Oxford University Press, Oxford).

Hart, Oliver D., and John Moore, 1990, Property rights and the nature of the firm, Journal of Political Economy 98, 1119-1158. 
Hausman, Jerry A., 1978, Specification tests in econometrics, Econometrica, 46, 12511271.

Hausman, Jerry A., 1983, Specification and estimation of simultaneous equation models, in Zvi Griliches and Michael Intriligator, ed.: The Handbook of Econometrics (North-Holland, New York), 391-448.

Haynes, G.W., C. Ou, and R. Berney, 1999, Small business borrowing from large and small banks, in J.L. Blanton, A. Williams, and S.L.W. Rhine, ed.: Business Access to Capital and Credit (Federal Reserve System Research Conference), 287-327.

Holmstrom, Bengt, 1999, The firm as a subeconomy, Journal of Law Economics and Organization, 15, 74-102.

Holmstrom, Bengt and Paul Milgrom, 1994, The firm as an incentive system, American Economic Review 84, 972-91.

Kashyap, Anil K and Jeremy C. Stein, 2000, What do a million observations on banks say about the transmission of monetary policy?, American Economic Review 90, 407-28.

Klein, Benjamin; Robert G. Crawford, and Armen A. Alchian, 1978, Vertical integration, appropriable rents, and the competitive contracting process, Journal of Law and Economics 21, 297-326.

Keeton, William R., 1995, Multi-office bank lending to small businesses: Some new evidence, Federal Reserve Bank of Kansas City Economic Review 81, 63-75.

LaPorta, Rafael, Florencio Lopez-de Silanes and Guillermo Zamarripa, 2001, Related lending, Working Paper, Harvard University.

Mullainathan, Sendhil and David Scharfstein, 2001, Do firm boundaries matter?, American Economic Review Papers and Proceedings 91, 195-199.

Nakamura, Leonard I., 1994, Small borrowers and the survival of the small bank: Is mouse bank mighty or Mickey?, Federal Reserve Bank of Philadelphia Business Review, November/December, 3-15.

Peek, Joe, and Eric S. Rosengren, 1996, Small business credit availability: How important is size of lender?, in A. Saunders and I. Walter, ed.: Financial System Design: The Case for Universal Banking (Irwin, Burr Ridge IL).

Peek, Joe and Eric S. Rosengren, 1998, Bank consolidation and small business lending: It's not just bank size that matters, Journal of Banking and Finance 22, 799-819. 
Petersen, Mitchell A., and Raghuram G. Rajan, 1994, The benefits of firm-creditor relationships: Evidence from small-business data, Journal of Finance 49, 3-37.

Petersen, Mitchell A., and Raghuram G. Rajan, 1995, The effect of credit market competition on lending relationships, Quarterly Journal of Economics 110, 407 443.

Petersen, Mitchell A., and Raghuram G. Rajan, 2002, Does distance still matter? The information revolution in small business lending, Journal of Finance, forthcoming.

Rajan, Raghuram G., 1992, Insiders and outsiders: The choice between informed and arm's-length debt, Journal of Finance 47, 1367-1399.

Rajan, Raghuram G., and Luigi Zingales, 1998, Power in a theory of the firm, Quarterly Journal of Economics 113, 387-432.

Rajan, Raghuram G., and Luigi Zingales, 2001, The firm as a dedicated hierarchy: A theory of the origins and growth of firms, Quarterly Journal of Economics 166, 805-851.

Sapienza, Paola, 2002, The effects of banking mergers on loan contracts, Journal of Finance, forthcoming.

Sharpe, Steven A., 1990, Asymmetric information, bank lending and implicit contracts: A stylized model of customer relationships, Journal of Finance 45, 1069-1087.

Smith, Janet K., 1987, Trade credit and information asymmetries, Journal of Finance 42, 863-872.

Stein, Jeremy C., 2002, Information production and capital allocation: Decentralized vs. hierarchical firms, Journal of Finance, forthcoming.

Strahan, Philip E., and James P. Weston, 1996, Small business lending and bank consolidation: Is there cause for concern?, Federal Reserve Bank of New York Current Issues in Economics and Finance 2, 1-6.

Strahan, Philip E., and James P. Weston, 1998, Small business lending and the changing structure of the banking industry, Journal of Banking and Finance 22, 821-45.

Simester, Duncan and Birger Wernerfelt, 2000, Determinants of asset ownership: A study of the carpentry trade, Working Paper, MIT.

Whinston, Michael D. 2001, Assessing the property rights and transaction-cost theories of firm scope, American Economic Review Papers and Proceedings 91, 184-188. 
Williamson, Oliver E., 1967, The economics of defense contracting: incentives and performance, in R. McKean, ed: Issues in Defense Economics (Columbia University Press, New York).

Williamson, Oliver E., 1975, Markets and Hierarchies: Analysis and Antitrust Implications (Collier Macmillan, New York).

Williamson, Oliver E., 1979, Transaction-cost economics: The governance of contractual relations, Journal of Law and Economics, 22, 233-61.

Williamson, Oliver E., 1985, The Economics Institutions of Capitalism (Free Press, New York).

Williamson, Oliver E., 1988, Corporate finance and corporate governance, Journal of Finance 43, 567-591. 


\section{Table 1: Summary Statistics \\ Panel A: Full Sample}

Panel A contains summary statistics for the variables used in all subsequent estimation. Distance is the distance between a firm and the bank branch or office it uses most often. Impersonal Relationship equals one if the firm interacts with its bank most often by phone or mail and zero if the interaction is in person. Relationship Length is the number of years the bank and the firm have been interacting (through lending, deposit, or service activities). Single Lender is a dummy variable which equals one if the firm has a single lender. Trade Credit Paid Late is the fraction of its trade credit the firm reports paying when it is past due. Bank Size is the assets of the bank from which the firm has its most recent loan. Number of Branches in Market is the number of branches which the firm's bank has in its market (MSA or county). Median Bank Size is the size of the median bank in the firm's market (MSA or county) weighted by branches. Open Market is the fraction of the previous ten years during which there were no restrictions on within-state branching in the firm's state. Firm Size is the assets of the firm. Loan Amount is the size of the most recent loan. Records is a dummy variable which equals one if the person answering the income statement and balance sheet questions for the firm had documentation such as financial statements or accounting records to help answer the questions. There are 1,131 observations in the sample.

\begin{tabular}{|l|rrrrr|}
\hline Variable & Mean & Std Dev & $25 \%$ & $50 \%$ & $75 \%$ \\
\hline Lending Methods & & & & & \\
Distance (miles) & 26.053 & 136.992 & 1.000 & 3.000 & 10.000 \\
Impersonal Relationship & 0.294 & 0.456 & 0.000 & 0.000 & 1.000 \\
Relationship Length (yrs) & 8.750 & 7.508 & 3.000 & 6.000 & 12.000 \\
Single Lender (1 = yes) & 0.499 & 0.500 & 0.000 & 0.000 & 1.000 \\
Trade Credit Paid Late & 0.352 & 0.208 & 0.250 & 0.250 & 0.500 \\
\hline Bank Characteristics & & & & & \\
Bank Size (\$B) & 8.883 & 23.147 & 0.163 & 0.956 & 7.685 \\
\# of Branches in Market & 21.486 & 45.494 & 1.000 & 5.000 & 25.000 \\
Bank Age (yrs) & 75.263 & 43.914 & 39.000 & 80.000 & 106.000 \\
Median Bank Size (\$B) & 6.159 & 13.426 & 0.196 & 1.203 & 6.077 \\
Open Market & 0.446 & 0.266 & 0.000 & 0.400 & 0.800 \\
\hline Firm Characteristics & & & & & \\
Firm Age & 1.842 & 8.865 & 8.000 & 13.000 & 22.000 \\
Firm Size (\$M) & 3.003 & 7.136 & 0.150 & 0.680 & 2.850 \\
Loan Amount (\$M) & 1.001 & 3.750 & 0.030 & 0.125 & 0.600 \\
Records (1 = yes) & 0.570 & 0.495 & 0.000 & 1.000 & 1.000 \\
\hline
\end{tabular}


Panel B: Means by Bank Size

Panel B contains the means of selected variables across four categories of bank size (less than $\$ 100 \mathrm{M}$, $\$ 100 \mathrm{M}-1 \mathrm{~B}, \$ 1 \mathrm{~B}-10 \mathrm{~B}$, and over $\$ 10 \mathrm{~B}$ in assets). Regressions estimating how the lending method variables depend upon bank size as well as on other firm and bank characteristics are contained in later tables.

\begin{tabular}{|l|cccc|}
\hline Variable & $<100 \mathrm{M}$ & $100 \mathrm{M}-1 \mathrm{~B}$ & $1 \mathrm{~B}-10 \mathrm{~B}$ & $10 \mathrm{~B}+$ \\
\hline Lending Methods & & & & \\
Distance (miles) & 14.947 & 9.488 & 19.302 & 71.363 \\
$\quad$ Impersonal Relationship & 0.168 & 0.216 & 0.375 & 0.406 \\
Relationship Length (yrs) & 9.384 & 9.261 & 8.762 & 7.389 \\
Single Lender (1=yes) & 0.616 & 0.496 & 0.497 & 0.410 \\
Trade Credit Paid Late & 0.325 & 0.374 & 0.340 & 0.349 \\
\hline Bank Characteristics & & & & \\
Bank Size (\$B) & 0.058 & 0.386 & 4.346 & 36.167 \\
\# of Branches in Market & 1.442 & 5.158 & 24.140 & 60.487 \\
Bank Age (years) & 49.111 & 67.858 & 86.543 & 92.679 \\
Median Bank Size (\$B) & 2.765 & 4.401 & 5.304 & 12.964 \\
Open Market & 0.305 & 0.413 & 0.497 & 0.544 \\
\hline Firm Characteristics & & & & \\
Firm Age (years) & 13.763 & 15.037 & 15.595 & 14.346 \\
Firm Size (\$M) & 0.704 & 1.752 & 3.860 & 5.695 \\
Loan Amount (\$M) & 0.180 & 0.375 & 1.198 & 2.402 \\
Records (1 = yes) & 0.474 & 0.562 & 0.576 & 0.654 \\
\hline Number of Observations & 190 & 379 & 328 & 234 \\
\hline
\end{tabular}




\section{Table 2: Determinants of Bank Size}

The dependent variable is $\operatorname{Ln}($ Bank Size). Bank Size is expressed in \$1000s and Firm Size and Loan Size are expressed in dollars before taking logs. Ln(Median Bank Size) is the log of the median bank assets in the firm's market (MSA or county) weighted by branches. Open Market is the fraction of the previous ten years during which there were no restrictions on within-state branching in the firm's state. We use Ln(Median Bank Size) and Open Market to instrument for Ln(Bank Size) in the models which follow. Each regression contains dummy variables for whether the loan is a line of credit, whether it is collateralized, and whether the firm has a checking account from the bank. Records is a dummy variable which equals one if the person answering the income statement and balance sheet questions for the firm had documentation such as financial statements or accounting records to help answer the questions. Each regression also includes dummies for the firm's industry (construction, retail, or services) and the year in which the loan was secured (1992-1994). Number of observations is 1,131 . Significance at the $10 \%, 5 \%$ and $1 \%$ levels denoted by $*, * *$, and $* * *$ respectively.

\begin{tabular}{|c|c|c|}
\hline \multirow[t]{2}{*}{ Independent Variables } & \multicolumn{2}{|c|}{ Models } \\
\hline & 1: OLS & 2: OLS \\
\hline \multirow{2}{*}{\multicolumn{3}{|c|}{ Bank and Market Characteristics }} \\
\hline & & $0.222^{* * *}$ \\
\hline Ln(Median Bank Size) & & $(0.032)$ \\
\hline \multirow[t]{2}{*}{ Open Market } & & $0.438^{* * *}$ \\
\hline & & $(0.145)$ \\
\hline \multirow[t]{2}{*}{$\operatorname{Ln}(1+\#$ of Branches $)$} & & $0.594^{* * *}$ \\
\hline & & $(0.039)$ \\
\hline \multirow[t]{2}{*}{ Market Herfindahl } & & -0.226 \\
\hline & & $(0.541)$ \\
\hline \multirow[t]{2}{*}{ Ln(1 + Bank Age $)$} & & $0.523^{* * *}$ \\
\hline & & $(0.051)$ \\
\hline \multicolumn{3}{|l|}{ Firm and Contract Characteristics } \\
\hline \multirow[t]{2}{*}{ Ln(Firm Size $)$} & $0.125^{* *}$ & $0.099^{* *}$ \\
\hline & $(0.051)$ & $(0.040)$ \\
\hline \multirow[t]{2}{*}{ Ln(1 + Firm Age $)$} & $-0.172^{*}$ & $-0.224^{* * *}$ \\
\hline & $(0.094)$ & $(0.073)$ \\
\hline \multirow[t]{2}{*}{ Ln(Loan Amount) } & $0.277^{* * *}$ & $0.198^{* * *}$ \\
\hline & $(0.051)$ & $(0.040)$ \\
\hline \multirow[t]{2}{*}{ Line of Credit $(1=$ yes $)$} & 0.197 & 0.110 \\
\hline & $(0.141)$ & $(0.110)$ \\
\hline \multirow[t]{2}{*}{ Loan Collateralized $(1=$ yes $)$} & $-0.313^{* *}$ & -0.059 \\
\hline & $(0.134)$ & $(0.105)$ \\
\hline \multirow[t]{2}{*}{ Checking Account $(1=$ yes $)$} & $-0.467^{* *}$ & $-0.869^{* * *}$ \\
\hline & $(0.210)^{* * *}$ & $(0.166)$ \\
\hline \multirow[t]{2}{*}{ Firm in MSA $(1=$ yes $)$} & $1.220^{* * *}$ & 0.040 \\
\hline & $(0.140)$ & $(0.151)$ \\
\hline \multirow[t]{2}{*}{ Records $(1=$ yes $)$} & $0.240^{* *}$ & $0.178^{*}$ \\
\hline & $(0.121)$ & $(0.094)$ \\
\hline Adjusted $\mathrm{R}^{2}$ & 0.218 & 0.526 \\
\hline
\end{tabular}




\section{Table 3: Distance Between the Firm and its Bank}

The dependent variable is the log of one plus the distance (in miles) between the firm and the bank branch or office which it uses most often. Ln(Bank Size) is the log of bank assets. Bank Size is expressed in $\$ 1000$ s and Firm Size and Loan Size are expressed in dollars before taking logs. In column 2, we report instrumental-variable estimates where the instruments for Ln(Bank Size) are Ln(Median Bank Size), the $\log$ of the median assets of banks in the area where the firm is located, and Open Market, the fraction of the previous ten years during which there were no restrictions on within-state branching in the firm's state. The number of branches in the market includes only branches of the bank from which the firm borrows. Each regression contains dummy variables for whether the loan is a line of credit, whether it is collateralized, and whether the firm has a checking account from the bank. Records is a dummy variable which equals one if the person answering the income statement and balance sheet questions for the firm had documentation such as financial statements or accounting records to help answer the questions. Each regression also includes dummies for the firm's industry (construction, retail, or services) and the year in which the loan was secured (1992-1994). Number of observations is 1,131. Significance at the $10 \%, 5 \%$ and $1 \%$ levels denoted by $* * *$, and $* * *$ respectively.

\begin{tabular}{|c|c|c|}
\hline \multirow{2}{*}{ Independent Variables } & \multicolumn{2}{|c|}{ Models } \\
\hline & 1: OLS & 2: IV \\
\hline \multicolumn{3}{|l|}{ Bank } \\
\hline Ln(Bank Size) & $\begin{array}{l}0.184^{* * *} \\
(0.021)\end{array}$ & $\begin{array}{l}0.296^{* * *} \\
(0.078)\end{array}$ \\
\hline $\operatorname{Ln}(1+\#$ of Branches $)$ & $\begin{array}{l}-0.385^{* * *} \\
(0.031)\end{array}$ & $\begin{array}{l}-0.467^{* * *} \\
(0.063)\end{array}$ \\
\hline Market Herfindahl & $\begin{array}{l}-0.352 \\
(0.392)\end{array}$ & $\begin{array}{l}-0.455 \\
(0.403)\end{array}$ \\
\hline Ln(1 + Bank Age $)$ & $\begin{array}{c}0.002 \\
(0.038) \\
\end{array}$ & $\begin{array}{l}-0.049 \\
(0.052)\end{array}$ \\
\hline \multicolumn{3}{|l|}{ Firm and Contract Characteristics } \\
\hline Ln(Firm Size) & $\begin{array}{c}0.028 \\
(0.030)\end{array}$ & $\begin{array}{c}0.018 \\
(0.031)\end{array}$ \\
\hline $\operatorname{Ln}(1+$ Firm Age $)$ & $\begin{array}{l}-0.216^{* * *} \\
(0.054)\end{array}$ & $\begin{array}{l}-0.189^{* * *} \\
(0.058)\end{array}$ \\
\hline Ln(Loan Amount) & $\begin{array}{l}0.076^{* *} \\
(0.030)\end{array}$ & $\begin{array}{c}0.049 \\
(0.035)\end{array}$ \\
\hline Line of Credit $(1=$ yes $)$ & $\begin{array}{c}0.121 \\
(0.082)\end{array}$ & $\begin{array}{c}0.107 \\
(0.083)\end{array}$ \\
\hline Loan Collateralized $(1=$ yes $)$ & $\begin{array}{c}0.049 \\
(0.078)\end{array}$ & $\begin{array}{c}0.066 \\
(0.079)\end{array}$ \\
\hline Checking Account $(1=$ yes $)$ & $\begin{array}{l}-0.870^{* * *} \\
(0.125)\end{array}$ & $\begin{array}{l}-0.758^{* * *} \\
(0.147)\end{array}$ \\
\hline Firm in MSA $(1=$ yes $)$ & $\begin{array}{l}0.255^{* *} \\
(0.105)\end{array}$ & $\begin{array}{l}0.200^{*} \\
(0.112)\end{array}$ \\
\hline Records $(1=$ yes $)$ & $\begin{array}{l}-0.026 \\
(0.070)\end{array}$ & $\begin{array}{l}-0.046 \\
(0.072)\end{array}$ \\
\hline Adjusted $\mathrm{R}^{2}$ & 0.269 & 0.235 \\
\hline
\end{tabular}


Table 4: Impersonal Communication Between the Firm and its Bank

The dependent variable is one if the bank and firm communicate impersonally (by phone or mail) and zero if they communicate in person. A logit model was estimated. Ln(Bank Size) is the log of bank assets. Bank Size is expressed in $\$ 1000$ s and Firm Size and Loan Size are expressed in dollars before taking logs. In column 2, we report instrumental-variable estimates where Ln(Bank Size) is replaced with its predicted value based on Ln(Median Bank Size), the log of the median assets of banks in the area where the firm is located, and Open Market, the fraction of the previous ten years during which there were no restrictions on within-state branching in the firm's state (see Table 2, column 2). The number of branches in the market includes only branches of the bank from which the firm borrows. Each regression contains dummy variables for whether the loan is a line of credit, whether it is collateralized, and whether the firm has a checking account from the bank. Records is a dummy variable which equals one if the person answering the income statement and balance sheet questions for the firm had documentation such as financial statements or accounting records to help answer the questions. Each regression also includes dummies for the firm's industry (construction, retail, or services) and the year in which the loan was secured (19921994). Number of observations is 1,131 . Significance at the $10 \%, 5 \%$ and $1 \%$ levels denoted by $*$, **, and *** respectively.

\begin{tabular}{|c|c|c|}
\hline \multirow[t]{2}{*}{ Independent Variables } & \multicolumn{2}{|c|}{ Models } \\
\hline & 1: logit & 2: logit/IV \\
\hline $\begin{array}{l}\text { Bank and Market Characteristics } \\
\text { Ln(Bank Size) }\end{array}$ & $\begin{array}{l}0.196^{* * *} \\
(0.046)\end{array}$ & $\begin{array}{l}0.324^{* *} \\
(0.165)\end{array}$ \\
\hline $\operatorname{Ln}(1+\#$ of Branches $)$ & $\begin{array}{l}-0.267^{* * *} \\
(0.064)\end{array}$ & $\begin{array}{l}-0.365^{* * *} \\
(0.131)\end{array}$ \\
\hline Market Herfindahl & $\begin{array}{l}-0.808 \\
(0.907)\end{array}$ & $\begin{array}{l}-0.883 \\
(0.916)\end{array}$ \\
\hline Ln(1 + Bank Age $)$ & $\begin{array}{l}-0.132 \\
(0.082)\end{array}$ & $\begin{array}{l}-0.179 \\
(0.108)\end{array}$ \\
\hline Firm and Contract Characteristics & & \\
\hline Ln(Firm Size $)$ & $\begin{array}{l}0.259^{* * *} \\
(0.070)\end{array}$ & $\begin{array}{l}0.248^{* * *} \\
(0.070)\end{array}$ \\
\hline Ln(1 + Firm Age $)$ & $\begin{array}{l}-0.329^{* * *} \\
(0.119)\end{array}$ & $\begin{array}{l}-0.290^{* *} \\
(0.124)\end{array}$ \\
\hline Ln(Loan Amount) & $\begin{array}{c}0.082 \\
(0.066)\end{array}$ & $\begin{array}{c}0.049 \\
(0.075)\end{array}$ \\
\hline Line of Credit $(1=$ yes $)$ & $\begin{array}{l}0.659^{* * *} \\
(0.191)\end{array}$ & $\begin{array}{l}0.642^{* * *} \\
(0.190)\end{array}$ \\
\hline Loan Collateralized $(1=$ yes $)$ & $\begin{array}{c}0.215 \\
(0.170)\end{array}$ & $\begin{array}{c}0.245 \\
(0.170)\end{array}$ \\
\hline Checking Account $(1=$ yes $)$ & $\begin{array}{l}-1.128^{* * *} \\
(0.266)\end{array}$ & $\begin{array}{l}-0.982^{* * *} \\
(0.302)\end{array}$ \\
\hline Firm in MSA $(1=$ yes $)$ & $\begin{array}{l}0.687^{* * *} \\
(0.245)\end{array}$ & $\begin{array}{l}0.608^{* * *} \\
(0.255)\end{array}$ \\
\hline Records $(1=$ yes $)$ & $\begin{array}{l}-0.109 \\
(0.153)\end{array}$ & $\begin{array}{l}-0.115 \\
(0.154)\end{array}$ \\
\hline Pseudo $\mathrm{R}^{2}$ & 0.179 & 0.168 \\
\hline
\end{tabular}


Table 5: Relationship Length Between the Firm and its Bank

The dependent variable is log of one plus the length of the relationship between the firm and its bank (in years). $\operatorname{Ln}($ Bank Size) is the log of bank assets. Bank Size is expressed in \$1000s and Firm Size and Loan Size are expressed in dollars before taking logs. In column 2, we report instrumental-variable estimates where the instruments for $\operatorname{Ln}($ Bank Size) are Ln(Median Bank Size), the log of the median assets of banks in the area where the firm is located, and Open Market, the fraction of the previous ten years during which there were no restrictions on within-state branching in the firm's state. The number of branches in the market includes only branches of the bank from which the firm borrows. Each regression contains dummy variables for whether the loan is a line of credit, whether it is collateralized, and whether the firm has a checking account from the bank. Records is a dummy variable which equals one if the person answering the income statement and balance sheet questions for the firm had documentation such as financial statements or accounting records to help answer the questions. Each regression also includes dummies for the firm's industry (construction, retail, or services) and the year in which the loan was secured (19921994). Number of observations is 1,131 . Significance at the $10 \%, 5 \%$ and $1 \%$ levels denoted by $*, * *$, and *** respectively.

\begin{tabular}{|c|cc|}
\hline Independent Variables & \multicolumn{2}{|c|}{ Models } \\
& $1:$ OLS & $2: \mathrm{IV}$ \\
\hline Bank and Market Characteristics & & \\
Ln(Bank Size) & $-0.048^{* * *}$ & $-0.150^{* * *}$ \\
& $(0.012)^{* *}$ & $(0.044)$ \\
Ln(1 + \# of Branches) & $0.051^{* * *}$ & $0.125^{* * *}$ \\
& $(0.017)$ & $(0.035)$ \\
Market Herfindahl & 0.313 & $0.408^{*}$ \\
& $(0.215)^{* *}$ & $(0.225)$ \\
Ln(1 + Bank Age) & $0.108^{* * *}$ & $0.155^{* * *}$ \\
& $(0.021)$ & $(0.029)$ \\
\hline Firm and Contract Characteristics & & \\
Ln(Firm Size) & 0.022 & $0.031^{*}$ \\
& $(0.016)$ & $(0.017)$ \\
Ln(1 + Firm Age) & $0.607^{* * *}$ & $0.582^{* * *}$ \\
& $(0.030)$ & $(0.032)$ \\
Ln(Loan Amount) & $-0.045^{* * *}$ & -0.020 \\
Line of Credit $(1=$ yes $)$ & $(0.016)$ & $(0.020)$ \\
& 0.000 & 0.012 \\
Loan Collateralized $(1=$ yes $)$ & $(0.045)$ & $(0.046)$ \\
& -0.056 & -0.072 \\
Checking Account $(1=$ yes $)$ & $(0.043)$ & $(0.044)$ \\
& $0.446^{* * *}$ & $0.343^{* * *}$ \\
Firm in MSA $(1=$ yes $)$ & $(0.068)$ & $(0.082)$ \\
& $-0.165^{* * *}$ & $-0.115^{* *}$ \\
Records $(1=$ yes) & $(0.057)$ & $(0.063)$ \\
& -0.049 & -0.031 \\
& $(0.038)$ & $(0.040)$ \\
\hline Adjusted ${ }^{2}$ & 0.366 & 0.348 \\
\hline
\end{tabular}


Table 6: Exclusive Relationship Between the Firm and its Bank

The dependent variable is one if the bank is the firm's only lender, and zero otherwise. A logit model was estimated. $\operatorname{Ln}($ Bank Size) is the log of bank assets. Bank Size is expressed in $\$ 1000$ s and Firm Size and Loan Size are expressed in dollars before taking logs. In column 2, we report instrumental-variable estimates where $\operatorname{Ln}$ (Bank Size) is replaced with its predicted value based on $\operatorname{Ln}$ (Median Bank Size), the log of the median assets of banks in the area where the firm is located, and Open Market, the fraction of the previous ten years during which there were no restrictions on within-state branching in the firm's state (see Table 2, column 2). The number of branches in the market includes only branches of the bank from which the firm borrows. Each regression contains dummy variables for whether the loan is a line of credit, whether it is collateralized, and whether the firm has a checking account from the bank. Records is a dummy variable which equals one if the person answering the income statement and balance sheet questions for the firm had documentation such as financial statements or accounting records to help answer the questions. Each regression also includes dummies for the firm's industry (construction, retail, or services) and the year in which the loan was secured (1992-1994). Number of observations is 1,131 . Significance at the $10 \%, 5 \%$ and $1 \%$ levels denoted by $*, * *$, and $* * *$ respectively.

\begin{tabular}{|c|c|c|}
\hline \multirow[t]{2}{*}{ Independent Variables } & \multicolumn{2}{|c|}{ Models } \\
\hline & 1: logit & 2: logit/IV \\
\hline $\begin{array}{l}\text { Bank and Market Characteristics } \\
\text { Ln(Bank size) }\end{array}$ & $\begin{array}{l}-0.096^{* *} \\
(0.040)\end{array}$ & $\begin{array}{l}-0.526^{* * *} \\
(0.144)\end{array}$ \\
\hline $\operatorname{Ln}(1+\#$ of Branches $)$ & $\begin{array}{c}0.075 \\
(0.057)\end{array}$ & $\begin{array}{l}0.388^{* * *} \\
(0.116)\end{array}$ \\
\hline Market Herfindahl & $\begin{array}{l}-0.637 \\
(0.721)\end{array}$ & $\begin{array}{l}-0.242 \\
(0.732)\end{array}$ \\
\hline Ln(1 + Bank Age $)$ & $\begin{array}{c}0.115 \\
(0.071) \\
\end{array}$ & $\begin{array}{l}0.308^{* *} \\
(0.095) \\
\end{array}$ \\
\hline Firm and Contract Characteristics & & \\
\hline Ln(Firm Size $)$ & $\begin{array}{l}-0.318^{* * *} \\
(0.057)\end{array}$ & $\begin{array}{l}-0.283^{* * *} \\
(0.058)\end{array}$ \\
\hline Ln(1 + Firm Age $)$ & $\begin{array}{l}0.246^{* *} \\
(0.102)\end{array}$ & $\begin{array}{c}0.143 \\
(0.107)\end{array}$ \\
\hline Ln(Loan Amount) & $\begin{array}{l}0.112^{* *} \\
(0.056)\end{array}$ & $\begin{array}{l}0.219^{* * *} \\
(0.065)\end{array}$ \\
\hline Line of Credit $(1=$ yes $)$ & $\begin{array}{l}-0.078 \\
(0.150)\end{array}$ & $\begin{array}{l}-0.027 \\
(0.152)\end{array}$ \\
\hline Loan Collateralized $(1=$ yes $)$ & $\begin{array}{l}-0.351^{* *} \\
(0.142)\end{array}$ & $\begin{array}{l}-0.419^{* * *} \\
(0.145)\end{array}$ \\
\hline Checking Account $(1=$ yes $)$ & $\begin{array}{l}0.517^{* *} \\
(0.235)\end{array}$ & $\begin{array}{c}0.087 \\
(0.271)\end{array}$ \\
\hline Firm in MSA $(1=$ yes $)$ & $\begin{array}{l}-0.098 \\
(0.192)\end{array}$ & $\begin{array}{c}0.110 \\
(0.204)\end{array}$ \\
\hline Records $(1=$ yes $)$ & $\begin{array}{l}-0.120 \\
(0.128)\end{array}$ & $\begin{array}{l}-0.044 \\
(0.131)\end{array}$ \\
\hline Pseudo $\mathrm{R}^{2}$ & 0.062 & 0.067 \\
\hline
\end{tabular}


Table 7: Fraction of Trade Credit Paid Late

The dependent variable is the fraction of trade credit the firm pays late. A tobit model was estimated. $\mathrm{Ln}($ Bank Size) is the log of bank assets. Bank Size is expressed in $\$ 1000$ s and Firm Size and Loan Size are expressed in dollars before taking logs. In column 2, we report instrumental-variable estimates where $\mathrm{Ln}($ Bank Size) is replaced with its predicted value based on Ln(Median Bank Size), the log of the median assets of banks in the area where the firm is located, and Open Market, the fraction of the previous ten years during which there were no restrictions on within-state branching in the firm's state (see Table 2, column 2). The number of branches in the market includes only branches of the bank from which the firm borrows. Each regression contains dummy variables for whether the loan is a line of credit, whether it is collateralized, and whether the firm has a checking account from the bank. Records is a dummy variable which equals one if the respondent to the survey had documentation to help answer the questions. Bank Size Residual is the residual from the first-stage bank-size regression (Table 2, column 2) and is used to conduct a test of whether bank size is exogenous. Each regression also includes dummies for the firm's industry (construction, retail, or services) and the year in which the loan was secured (1992-1994). Number of observations is 546 . Significance at the $10 \%, 5 \%$ and $1 \%$ levels denoted by $* * *$, and $* * *$ respectively.

\begin{tabular}{|c|c|c|c|}
\hline \multirow[t]{2}{*}{ Independent Variables } & \multicolumn{3}{|c|}{ Models } \\
\hline & 1: tobit & 2: tobit/IV & 3: tobit \\
\hline $\begin{array}{l}\text { Bank and Market Characteristics } \\
\text { Ln(Bank Size) }\end{array}$ & $\begin{array}{c}0.006 \\
(0.006)\end{array}$ & $\begin{array}{l}0.044^{* *} \\
(0.021)\end{array}$ & $\begin{array}{l}0.044^{* *} \\
(0.021)\end{array}$ \\
\hline $\operatorname{Ln}(1+\#$ of Branches $)$ & $\begin{array}{l}-0.017^{* *} \\
(0.008)\end{array}$ & $\begin{array}{l}-0.044^{* * *} \\
(0.017)\end{array}$ & $\begin{array}{l}-0.044^{* * *} \\
(0.017)\end{array}$ \\
\hline Market Herfindahl & $\begin{array}{c}0.024 \\
(0.112)\end{array}$ & $\begin{array}{l}-0.016 \\
(0.114)\end{array}$ & $\begin{array}{l}-0.016 \\
(0.114)\end{array}$ \\
\hline Ln(1 + Bank Age $)$ & $\begin{array}{c}0.007 \\
(0.010)\end{array}$ & $\begin{array}{l}-0.010 \\
(0.014)\end{array}$ & $\begin{array}{l}-0.010 \\
(0.014)\end{array}$ \\
\hline Bank Size Residual (Hausman test) & & & $\begin{array}{l}-0.041^{*} \\
(0.023)\end{array}$ \\
\hline \multicolumn{4}{|l|}{ Firm and Contract Characteristics } \\
\hline Ln(Firm Size $)$ & $\begin{array}{l}-0.002 \\
(0.009)\end{array}$ & $\begin{array}{l}-0.005 \\
(0.009)\end{array}$ & $\begin{array}{l}-0.005 \\
(0.009)\end{array}$ \\
\hline Ln(1 + Firm Age $)$ & $\begin{array}{c}0.022 \\
(0.015)\end{array}$ & $\begin{array}{l}0.032^{* *} \\
(0.016)\end{array}$ & $\begin{array}{l}0.032^{* *} \\
(0.016)\end{array}$ \\
\hline Ln(Loan Amount) & $\begin{array}{l}-0.008 \\
(0.009)\end{array}$ & $\begin{array}{l}-0.017^{*} \\
(0.010)\end{array}$ & $\begin{array}{l}-0.017^{*} \\
(0.010)\end{array}$ \\
\hline Line of Credit $(1=$ yes $)$ & $\begin{array}{c}0.003 \\
(0.023)\end{array}$ & $\begin{array}{c}0.000 \\
(0.023)\end{array}$ & $\begin{array}{c}0.000 \\
(0.023)\end{array}$ \\
\hline Loan Collateralized $(1=$ yes $)$ & $\begin{array}{l}0.042^{*} \\
(0.022)\end{array}$ & $\begin{array}{l}0.050^{* *} \\
(0.022)\end{array}$ & $\begin{array}{l}0.050^{* *} \\
(0.022)\end{array}$ \\
\hline Checking Account $(1=$ yes $)$ & $\begin{array}{l}-0.003 \\
(0.039)\end{array}$ & $\begin{array}{c}0.036 \\
(0.045)\end{array}$ & $\begin{array}{c}0.036 \\
(0.045)\end{array}$ \\
\hline Firm in MSA $(1=$ yes $)$ & $\begin{array}{l}0.066^{* *} \\
(0.030)\end{array}$ & $\begin{array}{c}0.047 \\
(0.031)\end{array}$ & $\begin{array}{c}0.047 \\
(0.031)\end{array}$ \\
\hline Records $(1=$ yes $)$ & $\begin{array}{c}0.028 \\
(0.020) \\
\end{array}$ & $\begin{array}{c}0.022 \\
(0.020) \\
\end{array}$ & $\begin{array}{c}0.022 \\
(0.020) \\
\end{array}$ \\
\hline Log Likelihood & 12.425 & 14.090 & 14.180 \\
\hline
\end{tabular}

